\title{
Biorhythms in conifer seed germination during extended storage
}

\author{
J.P. Barnett ${ }^{1}$ and N.I. Mamonov² \\ 1 U.S. Department of Agriculture, Forest Service, Southern Forest Experiment Station, Pineville, LA, \\ U.S.A., and \\ ${ }^{2}$ Central Scientific Research Instifute of Forest Genetics and Selection, Voronezh, U.S.S.R.
}

\section{Introduction}

A proportion of sound seeds of conifer species do not germinate during certain periods of the year, even when conditions are favorable. Mamonov et al., (1986) report that the non-germinating seeds have apparently undergone physiological changes that affected germination. This phenomenon may be due to seasonal periodicity, or biorhythms. As early as the mid-1930's, Baldwin (1935) reported seasonal variation in the germination of red spruce (Picea rubens Sarg.) seeds. David (1951) and Shomer-llan (1964) also found seasonal trends in the seed viability of several pine species. In these latter two studies, germinative capacity was at a maximum in April and May and decreased to a minimum in November and December.

The existence of seasonal rhythms has been difficult to document, and the significance is still questioned. Some researchers have been able to confirm the existence of these fluctuations (Repina, 1974; Smurova, 1969), while others have not (Rostovsev et al., 1975). Biorhythms, also known as seasonal rhythms or periodicity, seem to be related to age of seeds, seed storage conditions and tree species. The concept is important because seeds may be incorrectly classified as non-viable if germination tests are conducted at a time of the year when the physiological activity of the seeds being tested is low.

In order to clarify the significance of biorhythms, independent observations of both freshly collected and stored seeds of several conifer species were conducted in the Soviet Union and in the United States.

\section{Materials and Methods}

Seeds from Scots pine (Pinus sylvestris L.), Norway spruce (Picea abies (L.) Karst.), and Siberian larch (Larix sibirica Ledel.) were used in germination tests conducted in the Soviet Union. Monthly tests were run in germinators that provided constant conditions (Mamonov et al., 1986). Eight 50-seed samples were used in each test. The tests were repeated with stored seeds that had been collected from 1977 
through 1982. Storage time averaged about 3 yr. All seeds had been dried to a moisture content of less than $10 \%$ and held in sealed containers at subfreezing temperatures during storage. At the end of the germination tests, ungerminated seeds were analyzed to determine their soundness. The proportion of germinated seeds was calculated for each testing period and species. The results of April germination tests were used as the control because numerous observations indicated that germination is usually at its maximum in this month.

Tests in the United States used 3 freshly collected half-sib seed lots of longleaf pine (Pinus palustris Mill.) and slash pine ( $P$. elliottii Engelm.). These seed lots were cleared of all empty seeds by flotation, divided to provide for 24 monthly tests and stored at $-18^{\circ} \mathrm{C}$ with moisture contents near $8 \%$. Tests were conducted with unstratified seeds using 200 seeds each for 3 replications. Standardized testing conditions were maintained throughout the testing period (Association of Official Seed Analysts, 1980). Average germination values (Czabator, 1962) and percentages were computed for each treatment replication. The germination value is a mathematical model that incorporates both speed and completeness of germination into a single equation and is the product of mean daily germination at $28 \mathrm{~d}$ and peak value. Larger values imply faster and more complete germination.

\section{Results and Discussion}

Analysis of the Soviet test data showed no periodicity in Scots pine and Norway spruce seeds during the 1st yr of storage, but germination of Siberian larch seeds decreased in March and September. After the 1st yr of storage, Scots pine seed germination decreased during the summer (June and July) and winter (December and January) months. Germination of spruce and larch seeds decreased, and then lower values were extended over more months (Table I).

Tests also indicated that the number of sound seeds that fail to germinate varies within a given year. Only a few freshly collected pine and spruce seeds failed to germinate during the 1st yr of storage, indirectly confirming a lack of periodicity during the 1st yr. Larch seeds, however, began to exhibit monthly differences in germination during the 1 st yr.

During extended storage, the number of viable seeds that would not germinate

Table I. Average monthly germination of Scots pine, Norway spruce and Siberian larch seeds.

\begin{tabular}{|c|c|c|c|c|c|c|}
\hline \multirow[t]{2}{*}{ Month } & \multicolumn{2}{|l|}{ Scots pine } & \multicolumn{2}{|c|}{ Norway spruce } & \multicolumn{2}{|c|}{ Siberian larch } \\
\hline & $\overline{\text { germ }}{ }^{\dagger}$ & $d i f f^{2}$ & germ & diff & $\overline{\text { germ }}$ & diff \\
\hline Jan. & $86 \pm 1.12$ & $-4.6 \star \star 3$ & $60 \pm 2.60$ & $-2.6 \star \star$ & $90 \pm 1.13$ & -2.0 * \\
\hline Feb. & $89 \pm 0.80$ & $0.9 \mathrm{NS}$ & $63 \pm 1.45$ & $-2.3 *$ & $87 \pm 2.60$ & $-2.6 * \star$ \\
\hline Mar. & $88 \pm 1.10$ & $1.5 \mathrm{NS}$ & $59 \pm 2.15$ & $-3.3 \star \star$ & $87 \pm 1.58$ & $-3.2 * *$ \\
\hline Apr. & $90 \pm 0.69$ & control & $68 \pm 1.60$ & control & $93 \pm 1.07$ & control \\
\hline May & $89 \pm 0.94$ & $0.9 \mathrm{NS}$ & $56 \pm 3.10$ & $-3.5 \star \star$ & $90 \pm 1.38$ & $1.7 \mathrm{NS}$ \\
\hline June & $86 \pm 1.76$ & $-2.1 \star$ & $64 \pm 1.99$ & $1.6 \mathrm{NS}$ & $95 \pm 1.14$ & $1.3 \mathrm{NS}$ \\
\hline July & $85 \pm 1.42$ & $-3.2^{\star \star}$ & $58 \pm 2.59$ & $-3.3 \star \star$ & $83 \pm 3.20$ & $-3.4 \star \star$ \\
\hline Aug. & $88 \pm 0.70$ & $2.0 \mathrm{NS}$ & $63 \pm 1.86$ & $-2.1 \star$ & $87 \pm 2.65$ & $-2.1 \star$ \\
\hline Sept. & $89 \pm 0.78$ & $1.0 \mathrm{NS}$ & $62 \pm 1.75$ & $-2.5 \star \star$ & $88 \pm 1.03$ & $-3.3 \star \star$ \\
\hline Oct. & $88 \pm 1.01$ & $1.6 \mathrm{NS}$ & $65 \pm 1.57$ & $1.3 \mathrm{NS}$ & $93 \pm 1.07$ & $0.0 \mathrm{NS}$ \\
\hline Nov. & $89 \pm 1.13$ & $0.8 \mathrm{NS}$ & $65 \pm 1.79$ & $1.2 \mathrm{NS}$ & $90 \pm 1.58$ & $1.6 \mathrm{NS}$ \\
\hline Dec. & $83 \pm 1.06$ & $-5.5 \star \star$ & $57 \pm 2.14$ & $-4.1 \star \star$ & $88 \pm 2.22$ & $-2.1 \star$ \\
\hline
\end{tabular}

1 Germination percentage and standard error.

2 Differences from the control (Aprit germination) with $t$ statistic.

$3 \star \star$ : significant difference at the 0.01 probability level; *: significant difference at the 0.05 probability level; NS: no significant difference. 
increased significantly and differences in germination corresponding to the seasons of the year became pronounced. Thus, during a period of the year when one expects to see diminished physiological activity, the number of seeds with lowered physiological activity increased 1.6, 2.2 and 1.5 times for pine, spruce and larch, respectively (Mamonov et al., 1986). Long-term data collected on stored seeds by the Central Research Institute of Forest Genetics and Selection in the Soviet Union showed the number of pine and spruce seeds that did not germinate in March was, respectively, 2.8 and 17.7 times greater than in April, and in November there were 5.4 and 5.1 times fewer non-germinating seeds than in December. These seasonal fluctuations in the numbers of viable non-germinated seeds are indirect evidence of biorhythms.
The greatest differences in the performance of the 2 pine species tested in the United States appeared to be due to the half-sib seed lots. However, many of the trends established in the Soviet tests were confirmed in the United States pine seed tests. Germination of 2 longleaf pine seed lots fluctuated 4 or $5 \%$ from the mean over the 24 mo period, but were essentially the same as the initial germination percentage after $2 \mathrm{yr}$ of storage. Viability of the other seed lot decreased over the storage period, but without a consistent seasonal trend. Germination values were much more variable than percentages in longleaf pine. Response varied by each halfsib seed lot and the time of testing. The most obvious trends were decreases in speed of germination in late summer or early fall and increases in the spring usually April or May (Fig. 1).
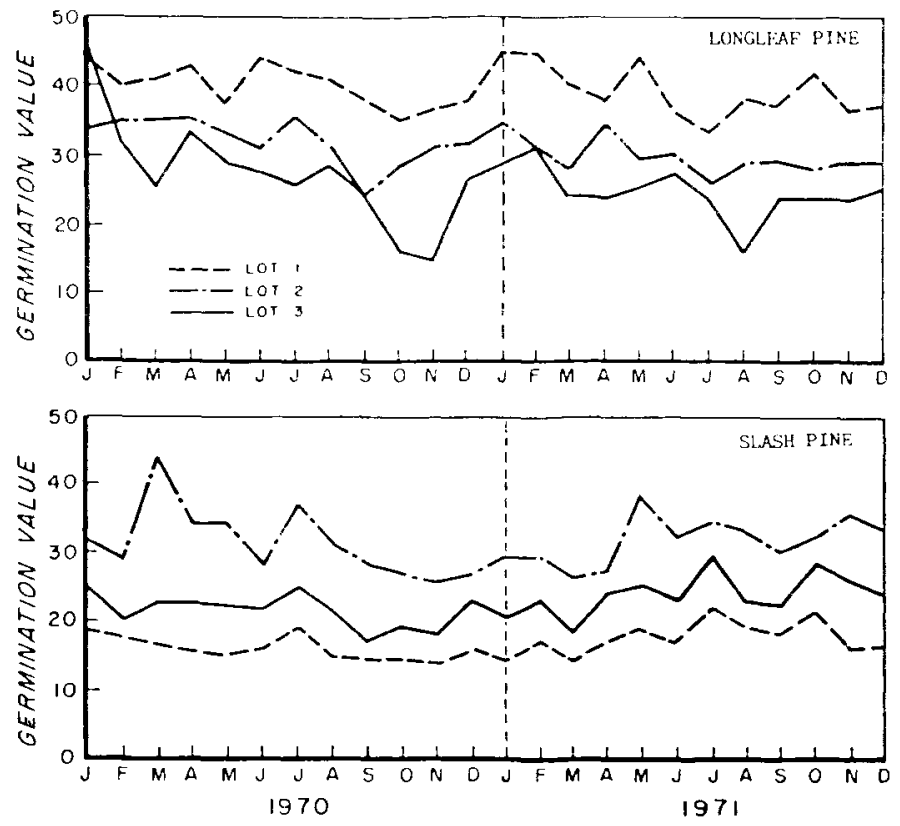

Fig. 1. Longleaf pine and slash pine germination values over a 2 yr period. 
The response of slash pine seeds was similar; however, the magnitude of differences in this more dormant-seeded species was less than for longleaf pine. Germination varied markedly among seed lots, but was fairly uniform over the 24 mo test period. Germination values were more variable and varied significantly with month (time) of testing (Fig. 1). Greater fluctuation in germination did occur during the 2nd year of testing. Slash pine germination values varied considerably among lots, but because lots responded differently with time of testing, overall seasonal trends are hard to identify. Germination values for 2 lois peaked in late spring/ early summer and decreased in August and September in both years of the test. There were indications that overall trends were different in the $2 \mathrm{yr}$.

The marked differences in response among seed lots and the possibility of changes with the age or storage of the seed could explain why germination of lots of pine species tested over time seems to improve with storage (Barnett, 1969; 1970). The data analyzed in this report support the concept of biorhythms in conifer seed germination and a number of conclusions were reached: 1) indications of biorhythms are more likely to be found in seeds of non-dormant species than in dormant species; 2) variation in biorhythm occurs from $1 \mathrm{yr}$ to another; 3 ) germination peaks occur in the early spring and lows occur in late summer; and 4) stored seeds show more seasonal fluctuation than freshly collected seeds. In addition, these studies indicate that the month (timing) of testing may influence the speed of germination more than it affects total germination.

\section{References}

Association of Official Seed Analysts (1980) Rules for testing seeds. J. Seed Technol. 3, 1. 126

Baldwin H.I. (1935) Seasonal variations in the germination of red spruce. Am. J. Bot. 22, 392394

Barnett J.P. (1969) Long-term storage of longleaf pine seeds. Tree Planters' Notes 20, 22-25

Barnett J.P. (1970) Storage of sand pine seeds. Tree Planters' Notes 21, 11-12

Czabator F.J. (1962) Germination value: an index combining speed and completeness of pine seed germination. For. Sci. 8, 386-396

David R. (1951) Activating germination of maritime pine seeds. Nav. Stores Rev. 61, 16-17, 23-24

Mamonov N.I., Pogorelova R.F. \& Spahova A.S. (1986) Storing seeds of main tree species. Agropromizdat Moscow, pp. 77 (in Russian)

Shomer-llan A. (1964) Influence of heat and dehydration on germination of pines. Isr. $J$. Bot. 13, 93-100

Repina N.I. (1974) Ob izmenii kachestva semian borezy borodvchatoi pri khranenii. Lesn. Khoz. 3, 150-151 (in Russian)

Rostovsev S.A., Lubich E.S. \& Solomonova A.A. (1975) K voprosu o sezonnosti prorastania semian sosni obiknovennoi. Lesn. Khoz. 4, 5760 (in Russian)

Smurova M.V. (1969) Sezonnaya izmenchivost kachestva semian sosni obiknovennoi pri dlitelnom khranenii. Bul. VNIALMI 5/57, 6-9 (in Russian) 